\title{
Draft genome sequence of Streptomyces sp. MWW064 for elucidating the rakicidin biosynthetic pathway
}

\author{
Hisayuki Komaki ${ }^{*}$, Arisa Ishikawa², Natsuko Ichikawa ${ }^{3}$, Akira Hosoyama ${ }^{3}$, Moriyuki Hamada', Enjuro Harunari ${ }^{2}$, \\ Takuya Nihira, ${ }^{4,5}$ Watanalai Panbangred ${ }^{5,6}$ and Yasuhiro Igarashi ${ }^{2}$
}

\begin{abstract}
Streptomyces sp. MWW064 (=NBRC 110611) produces an antitumor cyclic depsipeptide rakicidin D. Here, we report the draft genome sequence of this strain together with features of the organism and generation, annotation and analysis of the genome sequence. The $7.9 \mathrm{Mb}$ genome of Streptomyces sp. MWW064 encoded 7,135 putative ORFs, of which 6,044 were assigned with COG categories. The genome harbored at least three type I polyketide synthase (PKS) gene clusters, seven nonribosomal peptide synthetase (NRPS) gene clusters, and four hybrid PKS/NRPS gene clusters, from which a hybrid PKS/NRPS gene cluster responsible for rakicidin synthesis was successfully identified. We propose the biosynthetic pathway based on bioinformatic analysis, and experimentally proved that the pentadienoyl unit in rakicidins is derived from serine and malonate.
\end{abstract}

Keywords: Biosynthesis, Nonribosomal peptide synthetase, Polyketide synthase, Rakicidin, Streptomyces

\section{Introduction}

Rakicidin D is an inhibitor of tumor cell invasion isolated from the culture broth of an actinomycete strain MWW064 of the genus Streptomyces [1]. To date, five congeners rakicidins A, B, and E from Micromonospora and rakicidins $\mathrm{C}$ and D from Streptomyces have been reported [1-4]. Rakicidins share the 15-membered cyclic depsipeptide structure comprising three amino acids and a fatty acid modified with hydroxy and methyl substitutions. The most intriguing part of rakicidins is a rare unusual amino acid, 4-amino-2,4-pentadienoate (APDA), which is present only in a limited range of secondary metabolites of actinomycetes such as BE-43547 [5] and microtermolide [6, 7]. Despite the scarcity of APDA unit in nature, nothing is known about its biosynthesis. Recently, putative biosynthetic genes for rakicidin $\mathrm{D}$ were reported [8], but the data is incomplete, no detailed information is shown in the paper, and DNA sequences have not been registered in public databases. Hence, the biosynthesis of rakicidins has been actually unclear yet. In this study, we

\footnotetext{
* Correspondence: komaki-hisayuki@nite.go.jp

${ }^{1}$ Biological Resource Center, National Institute of Technology and Evaluation (NBRC), Chiba, Japan

Full list of author information is available at the end of the article
}

performed whole genome shotgun sequencing of the strain MWW064 to elucidate the biosynthetic mechanism of rakicidin $\mathrm{D}$. We herein present the draft genome sequence of Streptomyces sp. MWW064, together with the taxonomical identification of the strain, description of its genome properties and annotation of the gene cluster for rakicidin synthesis. We propose the rakicidin-biosynthetic mechanism predicted by bioinformatics analysis and confirmed by precursor-incorporation experiments.

\section{Organism information Classification and features}

In the course of screening for antitumor compounds from actinomycetes, Streptomyces sp. MWW064 was isolated from a marine sediment sample collected in Samut Sakhon province of Thailand and found to produce rakicidin $\mathrm{D}$ [1]. The general feature of this strain is shown in Table 1. This strain grew well on ISP 2 and ISP 4 agars. On ISP 5 and ISP 7 agars, the growth was poor. The color of aerial mycelia was white and that of the reverse side was pale red on ISP 2 agar. Diffusible pigments were dark orange on ISP 2 agar medium. Strain MWW064 formed extensively branched- substrate and aerial mycelia. The aerial mycelium formed flexuous 
Table 1 Classification and general features of Streptomyces sp. MWW064 [13]

\begin{tabular}{|c|c|c|c|}
\hline MIGS ID & Property & Term & Evidence code $\mathrm{e}^{\mathrm{a}}$ \\
\hline & Classification & Domain Bacteria & TAS [24] \\
\hline & & Phylum Actinobacteria & TAS [25] \\
\hline & & Class Actinobacteria & TAS [26] \\
\hline & & Order Actinomycetales & TAS [26-29] \\
\hline & & $\begin{array}{l}\text { Suborder } \\
\text { Streptomycineae }\end{array}$ & $\operatorname{TAS}[26,29]$ \\
\hline & & $\begin{array}{l}\text { Family } \\
\text { Streptomycetaceae }\end{array}$ & $\operatorname{TAS}[26,28-31]$ \\
\hline & & Genus Streptomyces & $\operatorname{TAS}[28,31-33]$ \\
\hline & & Species undetermined & - \\
\hline & & strain: MWW064 & TAS [1] \\
\hline & Gram stain & Gram-positive & NAS \\
\hline & Cell shape & Branched mycelia & IDA \\
\hline & Motility & Not reported & \\
\hline & Sporulation & Sporulating & IDA \\
\hline & $\begin{array}{l}\text { Temperature } \\
\text { range }\end{array}$ & $15^{\circ} \mathrm{C}$ to $37^{\circ} \mathrm{C}$ & IDA \\
\hline & $\begin{array}{l}\text { Optimum } \\
\text { temperature }\end{array}$ & $28^{\circ} \mathrm{C}$ & IDA \\
\hline & $\begin{array}{l}\mathrm{pH} \text { range; } \\
\text { Optimum }\end{array}$ & 5 to $9 ; 7$ & IDA \\
\hline & Carbon source & D-glucose, inositol & IDA \\
\hline MIGS-6 & Habitat & Marine sediment & TAS [1] \\
\hline MIGS-6.3 & Salinity & $0 \%$ to $3 \% \mathrm{NaCl}$ & IDA \\
\hline MIGS-22 & $\begin{array}{l}\text { Oxygen } \\
\text { requirement }\end{array}$ & Aerobic & IDA \\
\hline MIGS-15 & Biotic relationship & Free-living & IDA \\
\hline MIGS-14 & Pathogenicity & Not reported & \\
\hline MIGS-4 & $\begin{array}{l}\text { Geographic } \\
\text { location }\end{array}$ & $\begin{array}{l}\text { Samut Sakhon province, } \\
\text { Thailand }\end{array}$ & TAS [1] \\
\hline MIGS-5 & Sample collection & February 2, 2008 & NAS \\
\hline MIGS-4.1 & Latitude & $13^{\circ} 32^{\prime} 55^{\prime \prime} \mathrm{N}$ & NAS \\
\hline MIGS-4.2 & Longitude & $100^{\circ} 16^{\prime} 39^{\prime \prime} \mathrm{E}$ & NAS \\
\hline MIGS-4.4 & Altitude & $8.6 \mathrm{~m}$. above sea level & NAS \\
\hline
\end{tabular}

${ }^{a}$ Evidence codes - IDA: Inferred from Direct Assay; TAS: Traceable Author Statement (i.e., a direct report exists in the literature); NAS: Non-traceable Author Statement (i.e., not directly observed for the living, isolated sample, but based on a generally accepted property for the species, or anecdotal evidence). These evidence codes are from the Gene Ontology project [34]

spore chains at maturity. The spores were cylindrical, having a smooth surface. A scanning electron micrograph of this strain is shown in Fig. 1. Growth occurred at $15-37{ }^{\circ} \mathrm{C}$ (optimum $28{ }^{\circ} \mathrm{C}$ ) and $\mathrm{pH} 5-9$ (optimum $\mathrm{pH}$ 7). Strain MWW064 exhibited growth with 0-3\% (w/v) $\mathrm{NaCl}$ (optimum $0 \% \mathrm{NaCl}$ ). Strain MWW064 utilized glucose and inositol for growth. The gene sequence encoding 16S rRNA was obtained from GenBank/ EMBL/DDBJ databases (accession no. GU295447). A

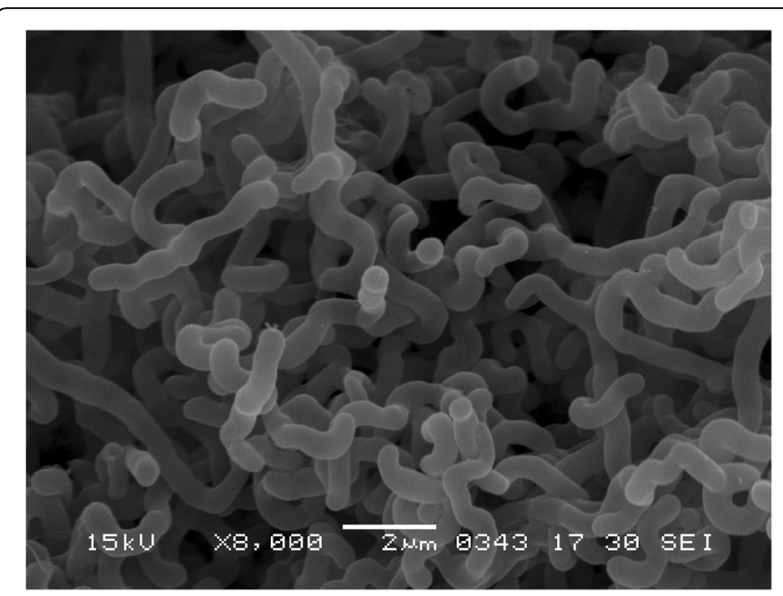

Fig. 1 Scanning electron micrograph of Streptomyces sp. MWW064 grown on $1 / 2$ ISP 2 agar for 7 days at $28^{\circ} \mathrm{C}$. Bar, $2 \mu \mathrm{m}$

phylogenetic tree was reconstructed on the basis of the $16 \mathrm{~S}$ rRNA gene sequence together with taxonomically close Streptomyces type strains using ClustalX2 [9] and NJPlot [10]. The phylogenetic analysis confirmed that the strain MWW064 belongs to the genus Streptomyces (Fig. 2).

\section{Chemotaxonomic data}

The isomer of diaminopimelic acid in the whole-cell hydrolysate was analyzed according to the method described by Hasegawa et al. [11]. Isoprenoid quinones and cellular fatty acids were analyzed as described previously [12]. The whole-cell hydrolysate of strain MWW064 contained LL-diaminopimelic acid as its diagnostic peptidoglycan diamino acid. The predominant menaquinones were identified as MK-9 $\left(\mathrm{H}_{2}\right)$, MK$9\left(\mathrm{H}_{4}\right)$ and MK-9 $\left(\mathrm{H}_{6}\right)$; MK-10 $\left(\mathrm{H}_{2}\right)$, MK-10 $\left(\mathrm{H}_{4}\right)$ and MK-10 $\left(\mathrm{H}_{6}\right)$ were also detected as minor components. The major cellular fatty acids were found to be anteiso- $C_{15: 0}$, iso- $C_{15: 0}, C_{16: 0}$, anteiso- $C_{17: 0}$, iso- $C_{17: 0}$ and iso- $\mathrm{C}_{16: 0}$.

\section{Genome sequencing information}

Genome project history

In collaboration between Toyama Prefectural University and NBRC, the organism was selected for genome sequencing to elucidate the rakicidin biosynthetic pathway. We successfully accomplished the genome project of Streptomyces sp. MWW064 as reported in this paper. The draft genome sequences have been deposited in the INSDC database under the accession number BBUY01000001-BBUY01000099. The project information and its association with MIGS version 2.0 compliance are summarized in Table 2 [13]. 


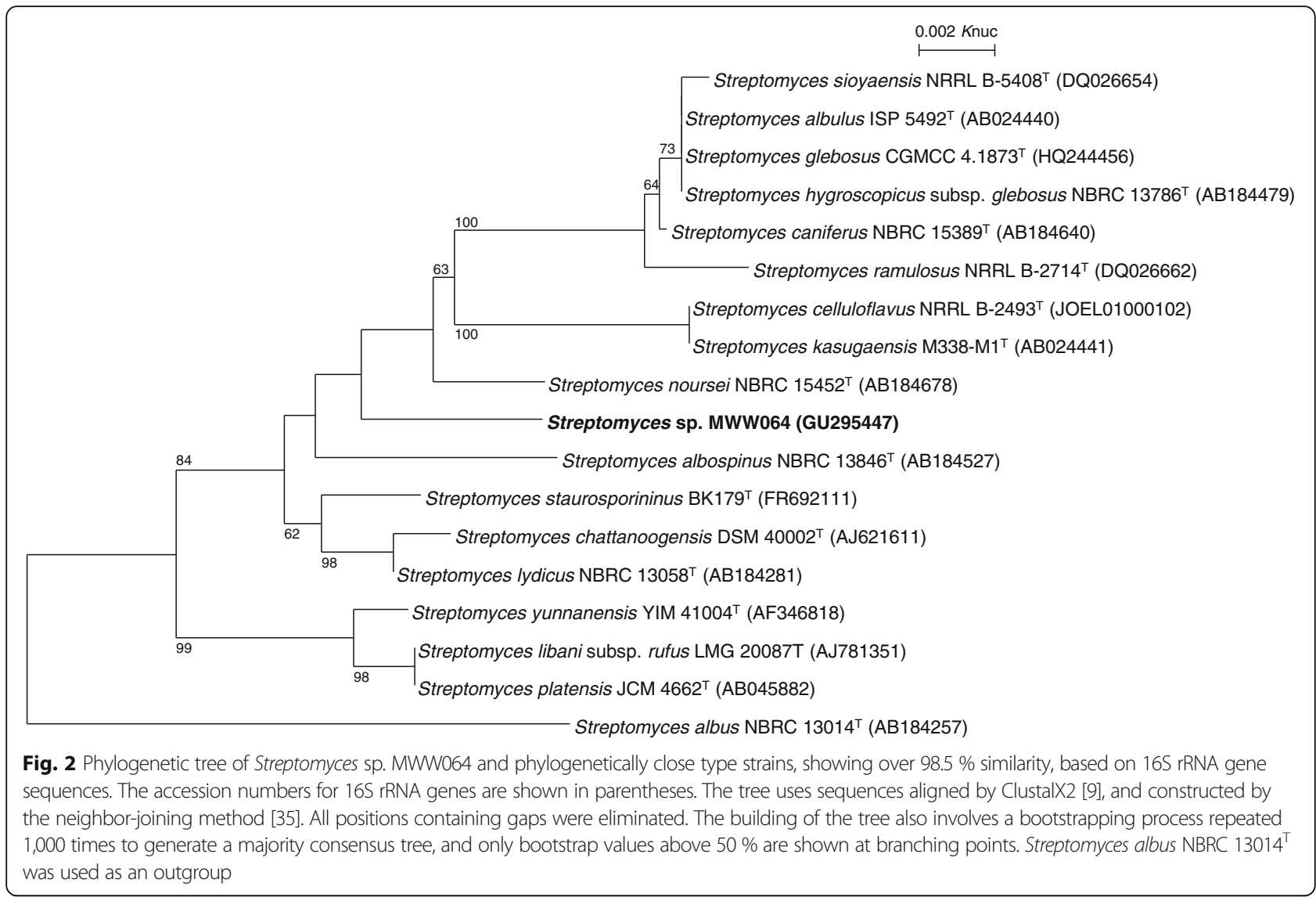

Table 2 Project information

\begin{tabular}{|c|c|c|}
\hline MIGS ID & Property & Term \\
\hline MIGS 31 & Finishing quality & Improved-high-quality draft \\
\hline MIGS-28 & Libraries used & $\begin{array}{l}454 \text { shotgun library, Illumina } \\
\text { paired-end library }\end{array}$ \\
\hline MIGS 29 & Sequencing platforms & $\begin{array}{l}454 \text { GS FLX+, Illumina } \\
\text { HiSeq1000 }\end{array}$ \\
\hline MIGS 31.2 & Fold coverage & $8.9 \times, 93.5 \times$, respectively \\
\hline MIGS 30 & Assemblers & Newbler v2.8, GenoFinisher \\
\hline \multirow[t]{6}{*}{ MIGS 32} & Gene calling method & Progidal \\
\hline & Locus Tag & SSP35 \\
\hline & GenBank ID & BBUY00000000 \\
\hline & GenBank Date of Release & February 20, 2016 \\
\hline & GOLD ID & Not registered \\
\hline & BIOPROJECT & PRJDB3538 \\
\hline \multirow[t]{2}{*}{ MIGS 13} & Source Material Identifier & NBRC 110611 \\
\hline & Project relevance & Industrial \\
\hline
\end{tabular}

Table 3 Genome statistics

\begin{tabular}{llc}
\hline Attribute & Value & \% of Total \\
\hline Genome size (bp) & $7,904,619$ & 100.0 \\
DNA coding (bp) & $6,855,885$ & 86.7 \\
DNA G + C (bp) & $5,597,799$ & 70.8 \\
DNA scaffolds & 99 & - \\
Total genes & 7,206 & - \\
Protein coding genes & 7,135 & 99.0 \\
RNA genes & 71 & 0.99 \\
Pseudogenes & - & - \\
Genes in internal clusters & 2,610 & 36.2 \\
Genes with function prediction & 4,515 & 62.7 \\
Genes assigned to CoGs & 6,044 & 83.9 \\
Genes with Pfam domains & 4,870 & 67.6 \\
Genes with signal peptides & 559 & 7.8 \\
Genes with transmembrane helices & 1,550 & 21.5 \\
CRISPR repeats & 1 & - \\
\hline
\end{tabular}


Table 4 Number of genes associated with general COG functional categories

\begin{tabular}{|c|c|c|c|}
\hline Code & Value & $\%$ age & Description \\
\hline J & 279 & 4.6 & Translation, ribosomal structure and biogenesis \\
\hline A & 4 & 0.1 & RNA processing and modification \\
\hline K & 696 & 11.5 & Transcription \\
\hline L & 452 & 7.5 & Replication, recombination and repair \\
\hline B & 6 & 0.1 & Chromatin structure and dynamics \\
\hline $\mathrm{D}$ & 55 & 0.9 & Cell cycle control, Cell division, chromosome partitioning \\
\hline V & 132 & 2.2 & Defense mechanisms \\
\hline T & 432 & 7.1 & Signal transduction mechanisms \\
\hline M & 294 & 4.9 & Cell wall/membrane biogenesis \\
\hline $\mathrm{N}$ & 33 & 0.5 & Cell motility \\
\hline$U$ & 95 & 1.6 & Intracellular trafficking and secretion \\
\hline O & 223 & 3.7 & Posttranslational modification, protein turnover, chaperones \\
\hline C & 386 & 6.4 & Energy production and conversion \\
\hline G & 474 & 7.8 & Carbohydrate transport and metabolism \\
\hline E & 651 & 10.8 & Amino acid transport and metabolism \\
\hline $\mathrm{F}$ & 134 & 2.2 & Nucleotide transport and metabolism \\
\hline $\mathrm{H}$ & 253 & 4.2 & Coenzyme transport and metabolism \\
\hline । & 323 & 5.3 & Lipid transport and metabolism \\
\hline P & 404 & 6.7 & Inorganic ion transport and metabolism \\
\hline Q & 385 & 6.4 & Secondary metabolites biosynthesis, transport and catabolism \\
\hline $\mathrm{R}$ & 1,032 & 17.1 & General function prediction only \\
\hline S & 440 & 7.3 & Function unknown \\
\hline- & 1,091 & 18.1 & Not in COGs \\
\hline
\end{tabular}

The total is based on the total number of protein coding genes in the genome

Table 5 Modular PKS and NRPS gene clusters in Streptomyces sp. MWW064

\begin{tabular}{|c|c|c|c|c|}
\hline Gene cluster & Encoded in & $\begin{array}{l}\text { No. of modular PKS } \\
\text { and NRPS genes }\end{array}$ & No. of modules & Backbone of predicted product \\
\hline pks/nrps-1 (rak) & scaffold 9 & 6 & 7 & $R-C_{3}-C_{3}-S e r-C_{2}-G l y-X$ \\
\hline pks/nrps-2 & scaffold 5 & 6 & 14 & $C_{2}-C_{2}-C_{2}-C_{2}-C_{2}-G l y-C_{2}-C_{2}-C_{2}-C_{2}-C_{2}-C_{2}-C_{2}-C_{2}$ \\
\hline pks/nrps-3 & scaffold 2 & 4 & 3 & $C_{?}-C_{?}-X$ \\
\hline pks/nrps-4 & scaffold 11 & 1 & 2 & $X-C_{2}$ \\
\hline$p k s-1$ & scaffold 18 & 5 & 5 & $C_{?}-C_{3}-C_{2}-C_{2}-C_{?}$ \\
\hline$p k s-2$ & scaffold 23 & 1 & 1 & C? \\
\hline other $p k s^{a}$ & scaffolds 11, 39, 45 & $>3$ & $>10$ & $C_{2}-C_{2}-C_{3}-C_{2}, C_{2}-C_{2}, C_{2}-C_{2}-C_{2}, C_{2}$ \\
\hline nrps-1 & scaffold 11 & 4 & 4 & $X-X-V a l-X$ \\
\hline nrps-2 & scaffold 18 & 3 & 3 & R-Val-X \\
\hline nrps-3 & scaffold 9 & 2 & 3 & R-Cys-mCys \\
\hline nrps-4 & scaffold 13 & 3 & 4 & Val-Gly-Ser-Pro \\
\hline nrps-5 & scaffold 2 & 1 & 1 & Ser \\
\hline nrps-6 & scaffold 12 & 1 & 1 & Thr \\
\hline other nrps ${ }^{a}$ & scaffolds 3, 5 & $>2$ & $>6$ & X-X-X-X-X, Cys \\
\hline
\end{tabular}

${ }^{a}$ not completely sequenced. $R$, starter unit; $C_{3}, C_{3}$ unit derived from methylmalonyl-CoA; $C_{2}, C_{2}$ unit derived from malonyl-CoA; $X$, unpredictable amino acid; $C_{?}$, unpredictable carbon unit derived from acyl-CoA; $m$ Cys, methylated cysteine 
Table 6 ORFs in the rakicidin-biosynthetic gene cluster of Streptomyces sp. MWW064

\begin{tabular}{|c|c|c|c|c|c|}
\hline ORF (locus tag) & Size (aa) & Deduced function & Protein homolog [origin] & Identity/similarity (\%) & Accession number \\
\hline SSP35_09_01970 & 243 & unknown & $\begin{array}{l}\text { hypothetical protein } \\
\text { [Streptomyces natalensis] }\end{array}$ & $63 / 73$ & WP_030067339 \\
\hline SSP35_09_01960 & 331 & transcriptional regulator & $\begin{array}{l}\text { hypothetical protein DT87_01625 } \\
\text { [Streptomyces sp. NTK 937] }\end{array}$ & $59 / 69$ & KDQ65969 \\
\hline SSP35_09_01950 & 358 & 3-oxoacyl-ACP synthase & $\begin{array}{l}\text { 3-oxoacyl-ACP synthase } \\
\text { [Streptomyces sp. NRRL S-920] }\end{array}$ & $77 / 87$ & WP_030791445 \\
\hline SSP35_09_01940 & 79 & $\mathrm{ACP}$ & $\begin{array}{l}\text { phosphopantetheine-binding protein } \\
\text { [Streptomyces bingchenggensis BCW-1] }\end{array}$ & $68 / 79$ & ADI05068 \\
\hline SSP35_09_01930 & 406 & ketosynthase & $\begin{array}{l}\text { 3-oxoacyl-ACP synthase } \\
\text { [Streptomyces sp. NRRL S-15] }\end{array}$ & $81 / 89$ & WP_031089521 \\
\hline SSP35_09_01920 & 146 & unknown & $\begin{array}{l}\text { methylmalonyl-CoA epimerase } \\
\text { [Salinispora pacifica] }\end{array}$ & $80 / 87$ & WP_018222873 \\
\hline SSP35_09_01910 (RakAB) & 2,902 & PKS & $\begin{array}{l}\text { hypothetical protein } \\
\text { [Streptomyces vitaminophilus] }\end{array}$ & $63 / 73$ & WP_018385948 \\
\hline SSP35_09_01900 (RakC) & 1,624 & PKS & $\begin{array}{l}\text { non-ribosomal peptide synthetase } \\
\text { [Micromonospora sp. M42] }\end{array}$ & $60 / 70$ & EWM63000 \\
\hline SSP35_09_01890 (RakD) & 1,126 & NRPS & $\begin{array}{l}\text { hypothetical protein } \\
\text { [Streptomyces vitaminophilus] }\end{array}$ & $68 / 78$ & WP_018385946 \\
\hline SSP35_09_01880 (RakEF) & 1,950 & PKS & $\begin{array}{l}\text { hypothetical protein } \\
\text { [Streptomyces vitaminophilus] }\end{array}$ & $64 / 73$ & WP_018385945 \\
\hline SSP35_09_01870 (RakG) & 1,556 & NRPS & $\begin{array}{l}\text { hypothetical protein, partial } \\
\text { [Micromonospora purpureochromogenes] }\end{array}$ & $64 / 74$ & WP_030498976 \\
\hline SSP35_09_01860 (RakH) & 1,565 & NRPS & $\begin{array}{l}\text { amino acid adenylation domain protein } \\
\text { [Nostoc punctiforme PCC 73102] }\end{array}$ & $38 / 55$ & ACC80782 \\
\hline SSP35_09_01850 & 563 & $A B C$ transporter & $\begin{array}{l}\text { hypothetical protein [Micromonospora } \\
\text { purpureochromogenes] }\end{array}$ & $62 / 73$ & WP_030498978 \\
\hline SSP35_09_01840 (RakL) & 251 & type-II thioesterase & $\begin{array}{l}\text { hypothetical protein [Streptomyces } \\
\text { vitaminophilus] }\end{array}$ & $64 / 73$ & WP_018385940 \\
\hline SSP35_09_01830 (RakN) & 1,013 & NRPS & $\begin{array}{l}\text { non-ribosomal peptide synthetase } \\
\text { [Micromonospora sp. M42] }\end{array}$ & $55 / 63$ & EWM63010 \\
\hline SSP35_09_01820 (RakO) & 331 & asparagine oxygenase & $\begin{array}{l}\text { clavaminate synthase } \\
\text { [Streptomyces sp. LaPpAH-202] }\end{array}$ & $64 / 75$ & WP_026235187 \\
\hline SSP35_09_01810 & 809 & unknown & penicillin amidase [Amycolatopsis nigrescens] & $63 / 74$ & WP_026359955 \\
\hline SSP35_09_01800 & 205 & transcriptional regulator & $\begin{array}{l}\text { putative LuxR family transcriptional regulator } \\
\text { [Streptomyces glaucescens] }\end{array}$ & $71 / 81$ & AlR96926 \\
\hline
\end{tabular}

SSP35 09 01910, SSP35 09 01900, SSP35 09 01890, SSP35 09 01880, SSP35 09 01870, SSP35 09_01860, SSP35 09_01840, SSP35 09 01830, and SSP35 09_01820 are corresponding to RakA plus RakB (RakAB), RakC, RakD, RakE plus RakF (RakEF), RakG, RakH, RakL, RakN, and RakO, previously reported in the reference [8], respectively, and SSP35_09_01940 may possibly be corresponding to Rakl

\section{Growth conditions and genomic DNA preparation}

Streptomyces sp. MWW064 was deposited in the NBRC culture collection with the registration number of NBRC 110611. Its monoisolate was grown on polycarbonate membrane filter (Advantec) on double diluted ISP 2 agar medium $(0.2 \%$ yeast extract, $0.5 \%$ malt extract, $0.2 \%$ glucose, $2 \%$ agar, $\mathrm{pH} 7.3$ ) at $28{ }^{\circ} \mathrm{C}$. High quality genomic DNA for sequencing was isolated from the mycelia with an EZ1 DNA Tissue Kit and a Bio Robot EZ1 (Qiagen) according to the protocol for extraction of nucleic acid from Gram-positive bacteria. The size, purity, and doublestrand DNA concentration of the genomic DNA were measured by pulsed-field gel electrophoresis, ratio of absorbance values at $260 \mathrm{~nm}$ and $280 \mathrm{~nm}$, and Quant-iT PicoGreen dsDNA Assay Kit (Life Technologies), respectively, to assess the quality of genomic DNA.

\section{Genome sequencing and assembly}

Shotgun and paired-end libraries were prepared and subsequently sequenced using 454 pyrosequencing technology and HiSeq1000 (Illumina) paired-end technology, respectively (Table 2). The $70 \mathrm{Mb}$ shotgun sequences and $739 \mathrm{Mb}$ paired-end sequences were assembled using Newbler v2.8 and subsequently finished using GenoFinisher [14] to yield 99 scaffolds larger than $500 \mathrm{bp}$. 


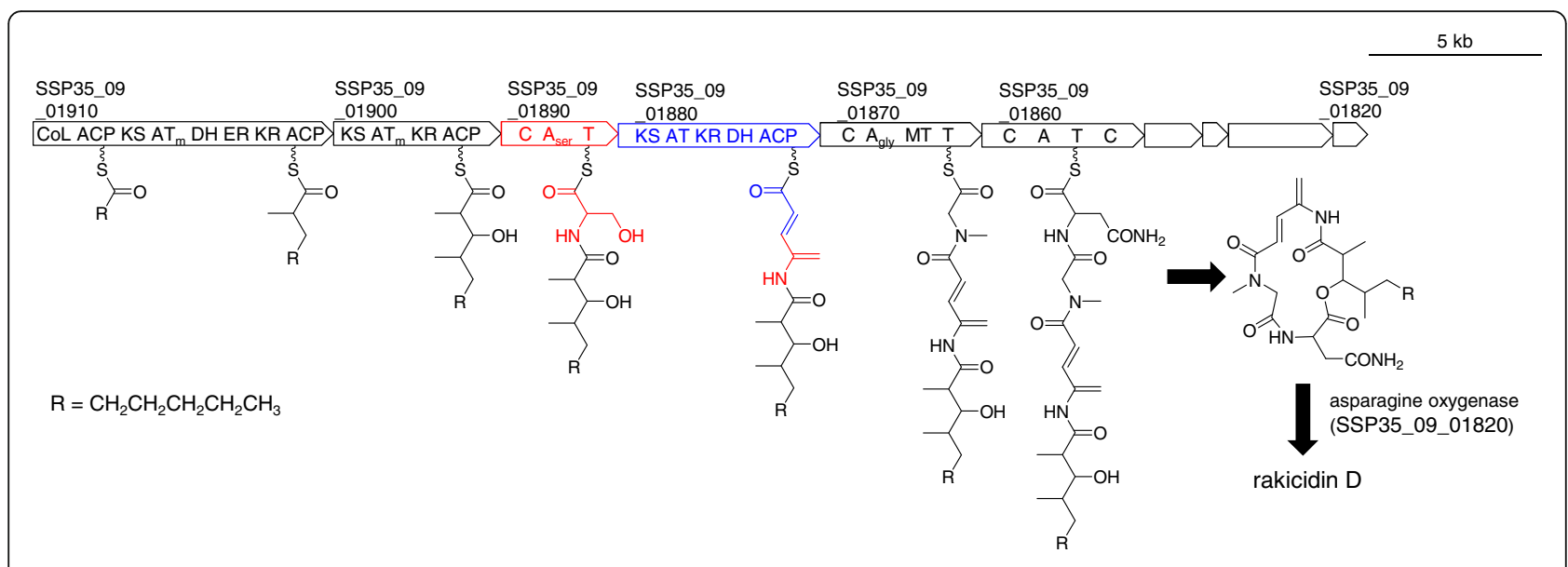

Fig. 3 Genetic map of rakicidin biosynthetic gene cluster of Streptomyces sp. MWW064 and the biosynthetic mechanism of rakicidin D

Table 7 Incorporation of ${ }^{13}$ C-labeled precursors into rakicidin D

\begin{tabular}{|c|c|c|c|}
\hline \multirow[t]{2}{*}{ Position } & \multirow[t]{2}{*}{$\delta_{C}$} & \multicolumn{2}{|c|}{ Relative enrichments ${ }^{a}$} \\
\hline & & {$\left[2-{ }^{13}\right.$ C]acetate } & {$\left[1-{ }^{13} \mathrm{C}\right]$-L-serine } \\
\hline 1 & 169.2 & 0.89 & 1.58 \\
\hline 2 & 54.9 & 1.14 & 1.19 \\
\hline 3 & 72.5 & 1.57 & 1.07 \\
\hline 4 & 172.7 & 1.31 & 1.95 \\
\hline 5 & 167.6 & 0.68 & 6.61 \\
\hline 6 & 52.5 & 0.77 & 1.15 \\
\hline 7 & 36.5 & 1.00 & 1.00 \\
\hline 8 & 166.0 & 0.77 & 1.43 \\
\hline 9 & 118.8 & 3.46 & 1.54 \\
\hline 10 & 138.4 & 1.03 & 13.97 \\
\hline 11 & 137.9 & 0.95 & 0.67 \\
\hline 12 & 117.1 & 1.02 & 1.33 \\
\hline 13 & 172.5 & 1.61 & 1.26 \\
\hline 14 & 41.7 & 1.86 & 1.36 \\
\hline 15 & 78.1 & 1.25 & 1.21 \\
\hline 16 & 33.9 & 1.91 & 1.39 \\
\hline 17 & 32.8 & 1.30 & 1.55 \\
\hline 18 & 27.0 & 2.64 & 1.26 \\
\hline 19 & 28.9 & 1.15 & 1.58 \\
\hline 20 & 31.3 & 3.37 & 1.43 \\
\hline 21 & 22.1 & 1.05 & 1.28 \\
\hline 22 & 14.0 & 3.37 & 1.61 \\
\hline 23 & 15.4 & 1.51 & 1.07 \\
\hline 24 & 13.3 & 1.75 & 1.32 \\
\hline
\end{tabular}

${ }^{a}{ }^{13} \mathrm{C}$ signal intensity of each peak in the labeled $\mathbf{1}$ divided by that of the corresponding signal in the unlabeled $\mathbf{1}$, respectively, normalized to give an enrichment ratio of $\mathbf{1}$ for the unenriched peak of $\mathrm{C} 7$. The numbers in bold type indicate ${ }^{13} \mathrm{C}$-enriched atoms from ${ }^{13} \mathrm{C}$-labeled precursors

\section{Genome annotation}

Coding sequences were predicted by Prodigal [15] and tRNA-scanSE [16]. The gene functions were annotated using an in-house genome annotation pipeline, and PKS- and NRPS-related domains were searched using the SMART and PFAM domain databases. PKS and NRPS gene clusters and their domain organizations were determined as reported previously [17]. Substrates of adenylation (A) and acyltransferase (AT) domains were predicted using antiSMASH [18]. BLASTP search against the NCBI nr databases were also used for predicting function of proteins encoded in the rakicidin biosynthetic gene cluster.

\section{Genome properties}

The total size of the genome is $7,870,697 \mathrm{bp}$ and the GC content is $71.1 \%$ (Table 3), similar to other genomesequenced Streptomyces members. Of the total 7,206 genes, 7,135 are protein-coding genes and 71 are RNA genes. The classification of genes into COGs functional categories is shown in Table 4. As for secondary metabolite pathways by modular PKSs and NRPSs, Streptomyces sp. MWW064 has at least four hybrid PKS/NRPS gene clusters, three type I PKS gene clusters, and seven NRPS gene clusters. According to the assembly line mechanism [19], we predicted the chemical backbones that each cluster will synthesize (Table 5), suggesting the potential of Streptomyces sp. MWW064 to produce diverse polyketide- and nonribosomal peptide-compounds as the secondary metabolites.

\section{Insights from the genome sequence Rakicidin biosynthetic pathway in Streptomyces sp. MWW064}

The chemical structure of rakicidin D suggested that it is synthesized by a hybrid PKS/NRPS pathway. Among 


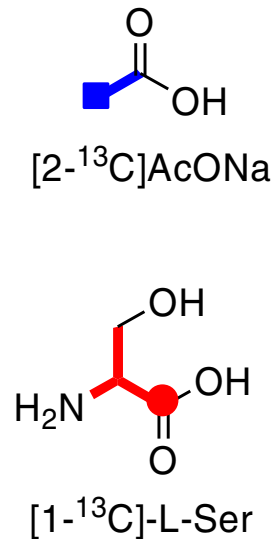

$\left[1-{ }^{13} \mathrm{C}\right]-\mathrm{L}-\mathrm{Ser}$

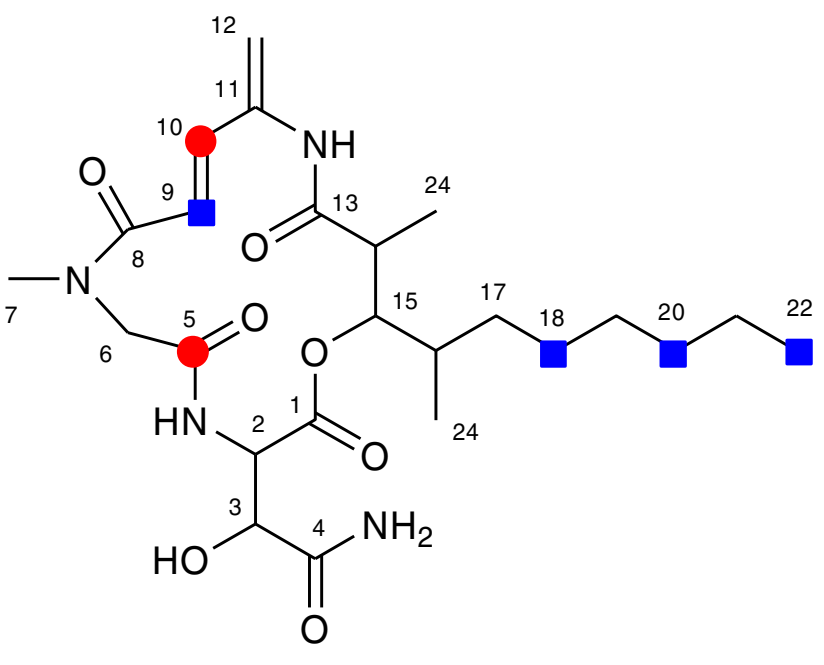

rakicidin $\mathrm{D}$

Fig. 4 Incorporation of ${ }^{13} \mathrm{C}$-labeled precursors into rakicidin $\mathrm{D}$

the four hybrid PKS/NRPS gene clusters present in Streptomyces sp. MWW064 (Table 5), pks/nrps-1 is most likely responsible for rakicidin synthesis because the carbon backbone of the predicted product $\left(\mathrm{R}-\mathrm{C}_{3}-\mathrm{C}_{3}-\mathrm{Ser}-\mathrm{C}_{2}-\right.$ Gly-X) is in good accordance with that of rakicidin D. Genes in pks/nrps-1 (Table 6) encode enzymes necessary for rakicidin biosynthesis (Fig. 3). This cluster contains three PKS genes (SSP35_09_01910, SSP35_09_01900, SSP35_09_01880) and three NRPS genes (SSP35_0 9_01890, SSP35_09_01870, SSP35_09_01860), corresponding to $\operatorname{rak} A B, \operatorname{rak} C, \operatorname{rakEF}, \operatorname{rak} D, \operatorname{rak} G$, and $\operatorname{rakH}$ [8], respectively. Based on the collinearity rule of modular PKS/NRPS pathways, it is deduced that RakAB loads a starter molecule (' $R$ ' in Fig. 3), and subsequently RakAB and RakC add a diketide chain to the starter by condensation of two methylmalonyl-CoA molecules, since the substrates of their AT domains are likely methylmalonyl-CoA ('AT $\mathrm{m}_{\mathrm{m}}$ ' in Fig. 3). An NRPS RakD and the remaining PKS RakEF are most likely involved in the APDA supply: the A domain of RakD has signature amino acid residues for serine, and RakEF contains a set of domains (AT, KR, DH) for malonate incorporation, ketoreduction, and dehydration to provide a double bond between $\mathrm{C} 9$ and $\mathrm{C} 10$. In addition, the $\mathrm{DH}$ domain in RakEF is also proposed to be responsible for the dehydration of the primary hydroxy group of the incorporated serine molecule on the basis of the following reasons although experimental evidences are required. First, no dehydratase gene is present near the rakicidin cluster. In the biosynthesis of dehydroalanine in bacterial peptides such as lantibiotics, a dehydratase catalyzes the exo-methylene formation from serine [20, 21]. Second, the order of $\mathrm{KR}$ and DH domains in RakEF is unusual: among the three hundred type I PKS genes for eighty actinomycete polyketides, the order of two domains is exclusively DH-KR [22]. The only exception can be seen in the PKS genes for enediynes in which the chain elongation is iteratively catalyzed as similar to type II PKS [23]. The unusual order of KR-DH may render an undescribed function to the DH domain of RakEF. After formation of APDA moiety, RakG is likely responsible for the condensation of glycine and the following $\mathrm{N}$ methylation, and $\mathrm{RakH}$ for asparagine condensation. Hydroxylation of asparagine would be catalyzed by asparagine hydroxylase encoded by rakO in the downstream of the cluster, to yield rakicidin $\mathrm{D}$. On the basis of the abovementioned bioinfomatic evidences, we here propose the biosynthetic pathway of rakicidin D as shown Fig. 3 .

\section{Identification of biosynthetic precursors of the APDA moiety}

To verify the predicted biosynthetic origin of the APDA unit, feeding experiments using ${ }^{13} \mathrm{C}$-labeled precursors were carried out. Inoculation, cultivation, extraction, and purification were performed in the same manner as previously reported [1]. Addition of sodium $\left[2-{ }^{13} \mathrm{C}\right]$ acetate or $\left[1-{ }^{13} \mathrm{C}\right]$-L-serine $(20 \mathrm{mg} / 100 \mathrm{ml}$ medium/flask, 10 flasks for $\left[2-{ }^{13} \mathrm{C}\right]$ acetate, 3 flasks for $\left[1-{ }^{13} \mathrm{C}\right]$-L-serine) was initiated at $48 \mathrm{~h}$ after inoculation and periodically carried out every $24 \mathrm{~h}$ for four times. After further incubation for $24 \mathrm{~h}$, the whole culture broths were extracted with 1-butanol and several steps of purification yielded $2.5 \mathrm{mg}$ and $1.7 \mathrm{mg}$ of ${ }^{13} \mathrm{C}$-labeled rakicidin $\mathrm{D}$, respectively. The ${ }^{13} \mathrm{C}$ NMR spectrum of these labeled rakicidin $\mathrm{D}$ is shown in Table 7 . Feeding of sodium $\left[2-{ }^{13} \mathrm{C}\right]$ acetate gave enrichments at $\mathrm{C} 9$ of the APDA unit and three 
carbons $\mathrm{C} 18, \mathrm{C} 20$, and $\mathrm{C} 22$ in the aliphatic chain of the fatty acid moiety. $\left[1-{ }^{13} \mathrm{C}\right]$-L-serine feeding enriched C10 of the APDA unit and the carbonyl carbon of Gly (C5). These results unambiguously indicated that the APDA unit is derived from an acetate and a serine (Fig. 4). Labeling of C5 by serine-feeding can be explained by the interconversion between glycine and serine by transformylase in primary metabolism for amino acid supply.

\section{Conclusions}

The 7.9 Mb draft genome of Streptomyces sp. MWW064, a producer of rakicidin $\mathrm{D}$ isolated from marine segment, has been deposited at GenBank/ENA/DDBJ under the accession number BBUY00000000. We successfully identified the PKS/NRPS hybrid gene cluster for rakicidin synthesis and proposed the plausible biosynthetic pathway. Labeled precursor incorporation experiments showed the APDA moiety is synthesized from serine and malonate. These finding will open up possibilities of genetic engineering to synthesize more potential rakicidin-based antitumor compounds and discovering new bioactive compounds possessing APDA units.

\section{Abbreviations}

A: Adenylation; ABC: ATP-binding cassette; ACP: Acyl carrier protein; APDA: 4amino-2,4-pentadienoate; AT: Acyltransferase; C: Condensation; CoA: Coenzyme A; CoL: CoA ligase; DDBJ: DNA Data Bank of Japan; DH: Dehydratase; ER: Enoylreductase; ISP: International Streptomyces project; KR: Ketoreductase; KS: Ketosynthase; NBRC: Biological Resource Center, National Institute of Technology and Evaluation; NMR: Nuclear magnetic resonance; NRPS: Nonribosomal peptide synthetase; PKS: Polyketide synthase; $\mathrm{T}$ : Thiolation

\section{Acknowledgements}

This research was supported by a Grant-in-aid for Scientific Research from the Ministry of Education, Culture, Sports, and Technology of Japan to Y.I. We are grateful to Dr. S. Kitani at Osaka University for thoughtful discussion on the biosynthesis of rakicidins. We also thank Ms. Yuko Kitahashi, Ms. Satomi Saitou and Ms. Chiyo Shibata for assistance to this study.

\section{Authors' contributions}

HK elucidated rakicidin-biosynthetic pathway and drafted the manuscript. Al carried out feeding experiments using labeled precursors. NI annotated the genome sequences. AH sequenced the genome. $\mathrm{MH}$ performed chemotaxonomic experiments. EH examined the features of the strain. TN coordinated collaboration between Japan and Thailand. WP isolated the strain. YI designed this study and edited the manuscript. All authors read and approved the final manuscript.

\section{Competing interests}

The authors declare that they have no competing interests.

\section{Author details}

${ }^{1}$ Biological Resource Center, National Institute of Technology and Evaluation (NBRC), Chiba, Japan. ${ }^{2}$ Biotechnology Research Center and Department of Biotechnology, Toyama Prefectural University, Toyama, Japan. ${ }^{3}$ NBRC, Tokyo, Japan. ${ }^{4}$ International Center for Biotechnology, Osaka University, Osaka, Japan. ${ }^{5}$ Mahidol University and Osaka University Collaborative Research Center on Bioscience and Biotechnology, Bangkok, Thailand. ${ }^{6}$ Department of Biotechnology, Faculty of Science, Mahidol University, Bangkok, Thailand.
Received: 24 February 2016 Accepted: 11 October 2016

Published online: 21 October 2016

\section{References}

1. Igarashi Y, Shimasaki R, Miyanaga S, Oku N, Onaka H, Sakurai H, Saiki I, Kitani S, Nihira T, Wimonsiravude W, et al. Rakicidin D, an inhibitor of tumor cell invasion from marine-derived Streptomyces sp. J Antibiot. 2010;63(9):563-5.

2. McBrien KD, Berry RL, Lowe SE, Neddermann KM, Bursuker I, Huang S, Klohr SE, Leet JE. Rakicidins, new cytotoxic lipopeptides from Micromonospora sp. fermentation, isolation and characterization. J Antibiot. 1995;48(12):1446-52.

3. Oku N, Matoba S, Yamazaki YM, Shimasaki R, Miyanaga S, Igarashi Y. Complete stereochemistry and preliminary structure-activity relationship of rakicidin A, a hypoxia-selective cytotoxin from Micromonospora sp. J Nat Prod. 2014;77(11):2561-5

4. Hu J, Wunderlich D, Sattler I, Feng X, Grabley S, Thiericke R. Rakicidin C, a new cyclic depsipeptide from Streptomyces sp. Eur. J. Org. Chem. 2000; 2000(19):3353-3356

5. Nishioka H, Nakajima S, Nagashima M, Kojiri K, Suda H. BE-43547 series substances, their manufacture with Streptomyces species, and their use as antitumor agents. Japan Patent 1998:JP 10147594 A 19980602.

6. Carr G, Poulsen M, Klassen JL, Hou Y, Wyche TP, Bugni TS, Currie CR, Clardy J. Microtermolides A and B from termite-associated Streptomyces sp. and structural revision of vinylamycin. Org Lett. 2012;14(11):2822-5.

7. Igarashi M, Shida T, Sasaki Y, Kinoshita N, Naganawa H, Hamada M, Takeuchi T. Vinylamycin, a new depsipeptide antibiotic, from Streptomyces sp. J Antibiot. 1999:52(10):873-9.

8. Albright JC, Goering AW, Doroghazi JR, Metcalf WW, Kelleher NL. Strainspecific proteogenomics accelerates the discovery of natural products via their biosynthetic pathways. J Ind Microbiol Biotechnol. 2014;41(2):451-9.

9. Larkin MA, Blackshields G, Brown NP, Chenna R, McGettigan PA, McWilliam H, Valentin F, Wallace IM, Wilm A, Lopez R, et al. Clustal W and Clustal X version 2.0. Bioinformatics. 2007;23(21):2947-8.

10. Perriere G, Gouy M. WWW-query: an on-line retrieval system for biological sequence banks. Biochimie. 1996;78(5):364-9.

11. Hasegawa T, Takizawa M, Tanida S. A rapid analysis for chemical grouping of aerobic actinomycetes. J Gen Appl Microbiol. 1983;29(4):319-22.

12. Hamada M, Yamamura H, Komukai C, Tamura T, Suzuki K, Hayakawa M. Luteimicrobium album sp. nov., a novel actinobacterium isolated from a lichen collected in Japan, and emended description of the genus Luteimicrobium. J Antibiot. 2012;65(8):427-31.

13. Field D, Garrity G, Gray T, Morrison N, Selengut J, Sterk P, Tatusova T, Thomson N, Allen MJ, Angiuoli SV, et al. The minimum information about a genome sequence (MIGS) specification. Nat Biotechnol. 2008;26(5):541-7.

14. Ohtsubo Y, Maruyama F, Mitsui H, Nagata Y, Tsuda M. Complete genome sequence of Acidovorax sp. strain KKS102, a polychlorinated-biphenyl degrader. J Bacteriol. 2012:194(24):6970-1.

15. Hyatt D, Chen GL, Locascio PF, Land ML, Larimer FW, Hauser LJ. Prodigal: prokaryotic gene recognition and translation initiation site identification. BMC Bioinformatics. 2010;11:119.

16. Lowe TM, Eddy SR. tRNAscan-SE: a program for improved detection of transfer RNA genes in genomic sequence. Nucleic Acids Res. 1997;25(5): 955-64.

17. Komaki H, Ichikawa N, Hosoyama A, Fujita N, Igarashi Y. Draft genome sequence of marine-derived Streptomyces sp. TP-A0598, a producer of antiMRSA antibiotic lydicamycins. Stand Genomic Sci. 2015;10:58.

18. Blin K, Medema MH, Kazempour D, Fischbach MA, Breitling R, Takano E, Weber T. antiSMASH 2.0-a versatile platform for genome mining of secondary metabolite producers. Nucleic Acids Res. 2013;41(Web Server issue):W204-12

19. Fischbach MA, Walsh CT. Assembly-line enzymology for polyketide and nonribosomal peptide antibiotics: logic, machinery, and mechanisms. Chem Rev. 2006;106(8):3468-96.

20. Bierbaum G, Gotz F, Peschel A, Kupke T, van de Kamp M, Sahl HG. The biosynthesis of the lantibiotics epidermin, gallidermin, Pep5 and epilancin K7. Antonie Van Leeuwenhoek. 1996;69(2):119-27.

21. Okesli A, Cooper LE, Fogle EJ, van der Donk WA. Nine post-translational modifications during the biosynthesis of cinnamycin. J Am Chem Soc. 2011; 133(34):13753-60.

22. Ichikawa N, Sasagawa M, Yamamoto M, Komaki H, Yoshida Y, Yamazaki S, Fujita N. DoBISCUIT: a database of secondary metabolite biosynthetic gene clusters. Nucleic Acids Res. 2013;41(Database issue):D408-14. 
23. Van Lanen SG, Shen B. Biosynthesis of enediyne antitumor antibiotics. Curr Top Med Chem. 2008;8(6):448-59.

24. Woese CR, Kandler O, Wheelis ML. Towards a natural system of organisms: proposal for the domains Archaea, Bacteria, and Eucarya. Proc Natl Acad Sci U S A. 1990;87(12):4576-9.

25. Garrity GM, Holt JG. The road map to the manual, vol. 1. Secondth ed. New York: Springer; 2001. p. 119-69.

26. Stackebrandt E, Rainey FA, Ward-Rainey NL. Proposal for a new hierarchic classification system, Actinobacteria classis nov. Int I Syst Bacteriol. 1997;47: 479-91.

27. Buchanan RE. Studies in the Nomenclature and Classification of the Bacteria: II. The Primary Subdivisions of the Schizomycetes. J Bacteriol. 1917;2(2):155-64.

28. Skerman VBD, McGowan V, Sneath PHA. Approved lists of bacterial names. Int J Syst Bacteriol. 1980;30:225-420.

29. Zhi XY, Li WJ, Stackebrandt E. An update of the structure and 16S rRNA gene sequence-based definition of higher ranks of the class Actinobacteria, with the proposal of two new suborders and four new families and emended descriptions of the existing higher taxa. Int I Syst Evol Microbiol. 2009;59(Pt 3):589-608.

30. Kim SB, Lonsdale J, Seong CN, Goodfellow M. Streptacidiphilus gen. nov., acidophilic actinomycetes with wall chemotype I and emendation of the family Streptomycetaceae (Waksman and Henrici (1943)AL) emend. Rainey et al. 1997. Antonie Van Leeuwenhoek. 2003;83(2):107-16.

31. Wellington EM, Stackebrandt E, Sanders D, Wolstrup J, Jorgensen NO. Taxonomic status of Kitasatosporia, and proposed unification with Streptomyces on the basis of phenotypic and $16 \mathrm{~S}$ rRNA analysis and emendation of Streptomyces Waksman and Henrici 1943, 339AL. Int I Syst Bacteriol. 1992;42(1):156-60.

32. Waksman SA, Henrici AT. The nomenclature and classification of the Actinomycetes. J Bacteriol. 1943;46(4):337-41.

33. Witt $D$, Stackebrandt E. Unification of the genera Streptoverticillium and Streptomyces, and amendation of Streptomyces Waksman and Henrici 1943, 339 AL. Syst Appl Microbiol. 1990;13:361-71.

34. Ashburner M, Ball CA, Blake JA, Botstein D, Butler H, Cherry JM, Davis AP, Dolinski K, Dwight SS, Eppig JT, et al. Gene ontology: tool for the unification of biology. The Gene Ontology Consortium. Nat Genet. 2000;25(1):25-9.

35. Saitou N, Nei M. The neighbor-joining method: a new method for reconstructing phylogenetic trees. Mol Biol Evol. 1987;4(4):406-25.

\section{Submit your next manuscript to BioMed Central and we will help you at every step:}

- We accept pre-submission inquiries

- Our selector tool helps you to find the most relevant journal

- We provide round the clock customer support

- Convenient online submission

- Thorough peer review

- Inclusion in PubMed and all major indexing services

- Maximum visibility for your research

Submit your manuscript at www.biomedcentral.com/submit 